Sustainability, Agri, Food and Environmental Research, (ISSN: 0719-3726), 10(X), 2022: http://dx.doi.org/

\title{
A review on bioflocculation using microalgae for nutrient removal from wastewater.
}

\section{Una revisión sobre la biofloculación utilizando microalgas para la eliminación de nutrientes de las aguas residuales.}

\author{
Swathy Krishna \\ Department of Civil Engineering, Adishankara Institute of Engineering and Technology \\ Kalady, India. Corresponding author mail id:swathikrishnaa4@gmail.com
}

\section{ABSTRACT}

In recent decades, the eutrophication of surface water has become a major environmental concern. Increased concentration of nutrients such as nitrogen and phosphorous lead to eutrophication condition which highlights the demand for effective and economical methods of removing nitrogen and phosphorous from wastewater. Bio flocculation using microalgae is an excellent candidate for satisfying the dual purpose of nutrient removal and wastewater treatment. It has so many advantages over conventional methods such as toxic free, no chemical is needed, low cost etc. In this review the bio flocculation of microalgae, its mechanisms, applications and harvesting methods are discussed.

Keywords: Bio flocculation, microalgae, nutrient removal, wastewater treatment.

\section{RESUMEN}

En las últimas décadas, la eutrofización de las aguas superficiales se ha convertido en una de las principales preocupaciones medioambientales. El aumento de la concentración de nutrientes como el nitrógeno y el fósforo conduce a una condición de eutrofización que resalta la demanda de métodos efectivos y económicos para eliminar el nitrógeno y el fósforo de las aguas residuales. La bio-floculación con microalgas es un excelente candidato para satisfacer el doble propósito de la eliminación de nutrientes y el tratamiento de aguas residuales. Tiene tantas ventajas sobre los métodos convencionales como libre de tóxicos, no se necesitan productos químicos, bajo costo, etc. En esta revisión se discute la biofloculación de microalgas, sus mecanismos, aplicaciones y métodos de recolección.

Palabras clave: Bio-floculación, microalgas, remoción de nutrientes, tratamiento de aguas residuales. 
Sustainability, Agri, Food and Environmental Research, (ISSN: 0719-3726), 10(X), 2022: http://dx.doi.org/

\section{INTRODUCTION}

Nowadays, the increasing industrial activities along with rapid urbanisation has lead to the generation of large amount of waste waters. Disposal of such waste waters without any appropriate methods has posed severe problems. The effulents that is released into the water bodies contains high concentration of nutrients such as nitrogen and phosphorous. Nutrient pollutants released to freshwater and coastal areas come from many diverse sources such as fertilizer industry, agriculture, urban waste water etc. High concentration of nutrients like nitrogen and phosphorous will lead to a condition known as eutrophication in water bodies, Eutrophication is a condition favourable for the development of harmful algal blooms ( $H A B$ ) which resulted in degradation of water quality and impairment of fresh water ecosystems. It also results in toxic productions, killing of fishes and altered biodiversity [1].

There are physical and chemical methods for nutrient removal from waste water such as coagulation, membrane filtration etc[4].But it is very costly and also produces high amount of sludges. Due to requiring large quantities of nutrients, especially nitrogen and phosphorous for growth, many species of microalgae have been proposed as an alternative biological treatment to remove nitrogen and phosphorous from different sources of waste water. High removal efficiencies of nitrogen and phosphorous have been recorded for several species of microalgae. Recent evidences indicates that formation of microalgae- bacteria flocculation (MBF) and fungi assisted microalgae pellets (FAMP) enhanced nutrient removal from waste water effulents [6].In bioflocculation, the aggregation of bacteria or fungi and microalgal cells create large flocs which accelerates the adsorption of suspended compounds from the surrounding medium. The cell wall of microalgaal cells secretes extracellular polymeric substance (EPS) into the surrounding medium which enhances the flocculation process. The accumulatiom of organic polymer substances called bioflocculants fundamentallyimprove the effectiveness of the flocculation procedures for microalgae harvesting which is due to the linkages, flanked by various colloidal particles of flocs. Another flocculation can occur naturally in certain microalgae in response to some environmental stresses, which is so called auto flocculation.

\section{BENEFITS OF USING MICROALGAE IN WASTE WATER TREATMENT}

1. Microalgae make a desirable treatment alternative by providing a renewable biomass feedstock forbiofuel production, while treating waste water as a growth medium

2. Microalgae have been known to be resilient to toxic contaminants of highly concentrated organic waste water.

3. Excellent at sorbing heavy metals and emerging contaminants.

4. Nutrient recovery in form of valuable biomass. 
Sustainability, Agri, Food and Environmental Research, (ISSN: 0719-3726), 10(X), 2022:

http://dx.doi.org/

5. Energy savings.

6. Pollutants and pathogen decrease and carbon dioxide emission reduction

\section{FLOCCULATION}

Generally, aggregation of particles as a result of polymer addition is known as flocculation. Flocculation is used as a unit of operation in waste water treatment. While in these applications, liquid is often the end product, for harvesting microalgae it is the biomass that is the end product. In microalge harvesting by flocculation, biomass contamination with a chemical flocculant is a major issue. Chemical flocculants can cause harm to the final products. In bioflocculation there is no need to add any chemical flocculant since the flocculation process will be enhanced by EPS(extracellular polymeric substance) excreted into the mediumby the microalgal cells itself [7]. Bioflocculation may be defined as the flocculation induced by extracellular polymer compounds such as polysaccharide and proteins derived from the microalgae.Flocculation is a process influenced by cell surface properties, cell concentration, $\mathrm{pH}$ of the environment and ionic strength. Crucial for flocculation process is mixing, which defines number and intensity of the collisions, enabling floc formation and influencing its properties. [2].

An ideal flocculant should be inexpensive, non toxic and effective at lower concentrations and it should preferably be derived from non-fossil fuel sources, thus being sustainable and renewable. Bio flocculation can be considered has most economical and effective method of waste water treatment, as it is toxic free and inexpensive. Also the harvested microalgae biomass has several secondary applications too.

Advantage of bioflocculation.

- Less energy consumption

- Low cost, since no chemicals are added

- Environmental friendliness

- Safety to humans

- Nutrient recovery in form of valuable biomass.

\section{MECHANISM OF FLOCCULATION}

Floc characteristics such as floc size, structure and density are determined by formation mechanism, and ultimately, they affect important parameters such as settling velocity and concentration factor. Settling velocity is a key parameter in the design of sedimentation vessels and concentration factor is the most important criteria to evaluate the overall efficiency of the process [2]. 
Sustainability, Agri, Food and Environmental Research, (ISSN: 0719-3726), 10(X), 2022: http://dx.doi.org/

Negatively charged microalgal cells are stable in dilute solution. This negative surface charge can be neutralized and destabilized withpositively charged flocculants. Flocculation of cell suspensions can be described by individual mechanisms and their combinations. (i) Charge neutralization. (ii) Electrostatic bridging mechanism (iii) sweeping flocculation (flocculation by massive precipitation of mineral). All the flocculation methods strongly depend upon the cell surface properties of microalgae (species, culture conditions and growth phase). In addition, the flocculation process is also affected by the composition of the culture medium.

The metals bind to the algal surface because of algal species, ionic charge of metal and chemical composition of metal ions.

- Ion exchange methods where ions present on algal surface are displaced by metal ions.

- Complexation between functional group and metal ions.

The algal cell wall is made up of polysaccharides, which provides functional group to act as binder during the flocculation process.Carboxyl group, sulfate group will enhance ionic bonding

Aminoacid, carboxyl group will enhance covalent bonding between metal ion and functional groups. The cell wall of algae secretes extracellular polymeric substance into the medium. EPS is a highly complex high molecular weight mixture excreted by microorganisms produced from cell lysis. It is a major component for keeping the aggreagates in a three-dimensional matrix. Extracellular polymeric substance retain the stable structure and form a 3D polymer network for cells to interact with each other, and mediate their adhesion to the surface of microagal cells [5].

\section{UTILIZATION OF MICROALGAE IN WASTE WATER TREATMENT}

Wastewater is used as culture medium for the growth of the microalgae. Usually in wastewater inorganic nutrients such as nitrogen, phosphorous, heavy metals etc will be present. During the culture period, microalgae uses nitrogen and phosphorous for their growth. That is, in the prsence of light microalgae uptake inorganic nutrients and releases oxygen required by the bacteria foer oxidation. Bacterias present in the waste water oxidise organic matter into inorganic compounds consuming oxygen. Microalgae also have the capacity to remove heavy metals as well as some toxic organic compounds. Finay, the microalgal biomass can be harvested and used for production of biofulels, and several by products[11]. And we will get treated wastewater. 


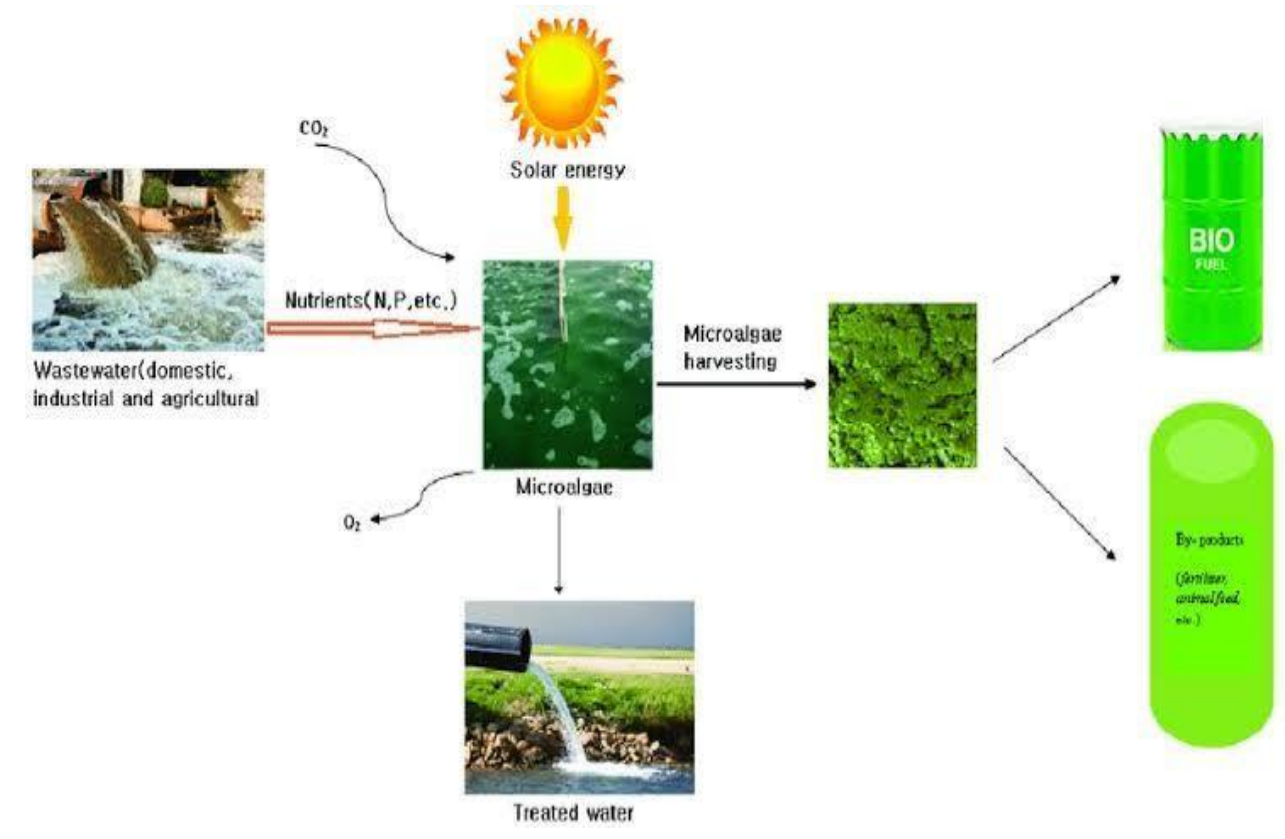

Fig 1: Utilization of microalgae in waste water treatment

\section{WASTEWATER TREATMENT AND NUTRIENT REMOVAL}

Microalgae is a good sequestor of heavy metals and nutrients from wastewater[6]. The big advantage of this process are using low cost raw materials, big adsorbing capacity and no production of secondary pollution. Moreover algae can be used to treat different industrial effulents and waste water containing heavy metals. Tremendous efforts have been made to microalgal biomass production economically viable by using waste waters instead of fresh waters. This includes the use of substitutes for culturing and dewatering of microalgal biomass. In this regard, use of industrial and domestic wastewater for microalgae cultivation has come into practice which is rich in nutrients. Conventionally, biological methods and chemical methods are used to remove nitrogen and phosphorous from wastewater to reduce the pollution. However, high cost and more sludge production are the disadvantage to this process. Whereas, use of microalgae for removal of nutrients from waste water reduces the cost and sludge production. Microalgae cells were able to removing nitrogen and phosphorous effectively from various types if waste waters and muncipal waste water and therefore reduce eutrophication and ecosystem damage in the downstream water sheds. However, the application of industrial wastewater in microalgae based biofuel production is limited due to high level of toxicants, nutrients, turbidity and sometimes colour. Nitrogen is the most significant nutrient for the production of microalgal biomass and its cellular components ie, proteins, aminoacids, amides, etc. 
Sustainability, Agri, Food and Environmental Research, (ISSN: 0719-3726), 10(X), 2022:

http://dx.doi.org/

Phosphorous is also one of the most significant nutrient for microalgal growth and also contain $1 \%-3 \% \mathrm{P}$ in the dry weight of microalgae[3]. Phosphorous plays a major role in algal cellular metabolic processes such as energy transfer, DNA and nucliec acid synthesis and forms many structural functional components required for the microalgae growth and development. Microalgae grown in phosphorous rich waste waters assimilate phosphorous as inorganic orthophosphate. These were stored with in the cells in the form of polyphosphate granules and this can be enough for the prolonged growth in the absense of phosphorous[1].

Fecal coliforms are indicators of water pollution. Algal growth indirectly reduce the bacterial growth through competetive utilization of nutrients and carbon sources from the waste water. Microalgal photosynthesis induces oxygen and $\mathrm{pH}$ variation in effluent which helps to reduce coliform amd other pathogenic bacteria. The light attenuation and $\mathrm{pH}$ increases algal density and turbidity, and the increased algal growth resulted in a decreased and destruction of fecal coliforms. Microalgal treatment is sustainable and efficient in the reduction of coliforms in effluent before being discarded from the sewage treatmentplants[10].

\section{HARVESTING OF MICROALGAE}

After the treatment, the microgae biomass have to be harvested. There are several methods for harvesting microalgae biomass as shown in the table 1 . The harvesting of microalgae depends on several factors mainly $\mathrm{pH}$ and mixing rate[7].

1. Effect of $\mathrm{pH}$

- It shows that certain alkaline medium might favour floc formations.

- Higher pH values cause -ve charge that can decrease spore aggregations.

2. Effect of mixing rate

- Flox formation does not takes place at lower mixing rate [3]

- Mixing rate at $125 \mathrm{rpm}$ was chosen as optimal mixing rate. 
Sustainability, Agri, Food and Environmental Research, (ISSN: 0719-3726), 10(X), 2022: http://dx.doi.org/

Table 1. Comparison of microalgal harvesting methods [5]

\begin{tabular}{|c|c|c|c|}
\hline Method & Advantages & Disadvantages & Harvesting (\%) \\
\hline $\begin{array}{l}\text { Centrifugation of } \\
\text { microalgae }\end{array}$ & $\begin{array}{l}\text { Cell recovery over } 90 \% \text {, can } \\
\text { handle most algal types with } \\
\text { rapid efficient cell harvesting, } \\
\text { reliable. }\end{array}$ & $\begin{array}{l}\text { High capital and operational costs, } \\
\text { energy intensive }\end{array}$ & $12-22$ \\
\hline $\begin{array}{l}\text { Filtration of } \\
\text { microalgae }\end{array}$ & $\begin{array}{l}\text { Cell recovery } 70-90 \% \text {, wide } \\
\text { variety of filter and membrane } \\
\text { types available, reliable, can } \\
\text { handle delicate cells. }\end{array}$ & $\begin{array}{l}\text { Highly dependent on algal species, } \\
\text { best suited to large algal cells, } \\
\text { clogging or fouling an issue, high } \\
\text { capital and operational costs. }\end{array}$ & $5-27$ \\
\hline $\begin{array}{l}\text { Sedimentation of } \\
\text { microalgae }\end{array}$ & $\begin{array}{l}\text { Cell recovery } 10-90 \% \text {, low cost, } \\
\text { potential for use as a first stage } \\
\text { to reduce energy input and cost } \\
\text { of subsequent stages. }\end{array}$ & $\begin{array}{l}\text { Algal species specific, best suited } \\
\text { to dense (heavy) non-motile cells, } \\
\text { separation can be slow or } \\
\text { unreliable, low final concentration }\end{array}$ & $0.5-3.0$ \\
\hline Flotation of microalgae & $\begin{array}{l}\text { Cell recovery } 50-90 \% \text {, can be } \\
\text { more rapid than sedimentation, } \\
\text { possibility to combine with } \\
\text { gaseous transfer. }\end{array}$ & $\begin{array}{l}\text { Algal species specific, high capital } \\
\text { and operational cost, flocculants } \\
\text { usually required }\end{array}$ & $3-6$ \\
\hline $\begin{array}{l}\text { Flocculation }+ \\
\text { sedimentation of } \\
\text { microalgalflocs }\end{array}$ & $\begin{array}{l}\text { Cell recovery over } 90 \% \text {, wide } \\
\text { range of flocculants available, } \\
\text { variable price, can below-cost }\end{array}$ & $\begin{array}{l}\text { Removal of flocculants, chemical } \\
\text { contamination, fragile flocs and/or } \\
\text { longer settlingtimes }\end{array}$ & $3-8$ \\
\hline $\begin{array}{l}\text { Electroflocculation }+ \\
\text { sedimentation or } \\
\text { flotation of } \\
\text { microalgalflocs }\end{array}$ & $\begin{array}{l}\text { Cell recovery over } 90 \% \text {, low } \\
\text { energy consumption, possibility } \\
\text { to combine with flotation in one } \\
\text { step }\end{array}$ & $\begin{array}{l}\text { Contamination of biomass with } \\
\text { metal ions, active chlorine can be } \\
\text { formed by treatment of sea water }\end{array}$ & $\begin{array}{l}10 \\
\text { (sediment } \\
\text { ation) } \\
30-40 \\
\text { (flotation) }\end{array}$ \\
\hline $\begin{array}{l}\text { Magnetic separation of } \\
\text { microalgae }\end{array}$ & $\begin{array}{l}\text { Cell recovery over } 90 \% \text {, fast, } \\
\text { can be considered as one } \\
\text { harvesting step, cost } \\
\text { effective. }\end{array}$ & $\begin{array}{l}\text { Magnetic modification of biomass } \\
\text { required, subsequent obtaining of } \\
\text { pure andmagneticparticle-free } \\
\text { biomass canbe problematic. }\end{array}$ & $10-20$ \\
\hline
\end{tabular}




\section{APPLICATION OF HARVESTED BIOMASS}

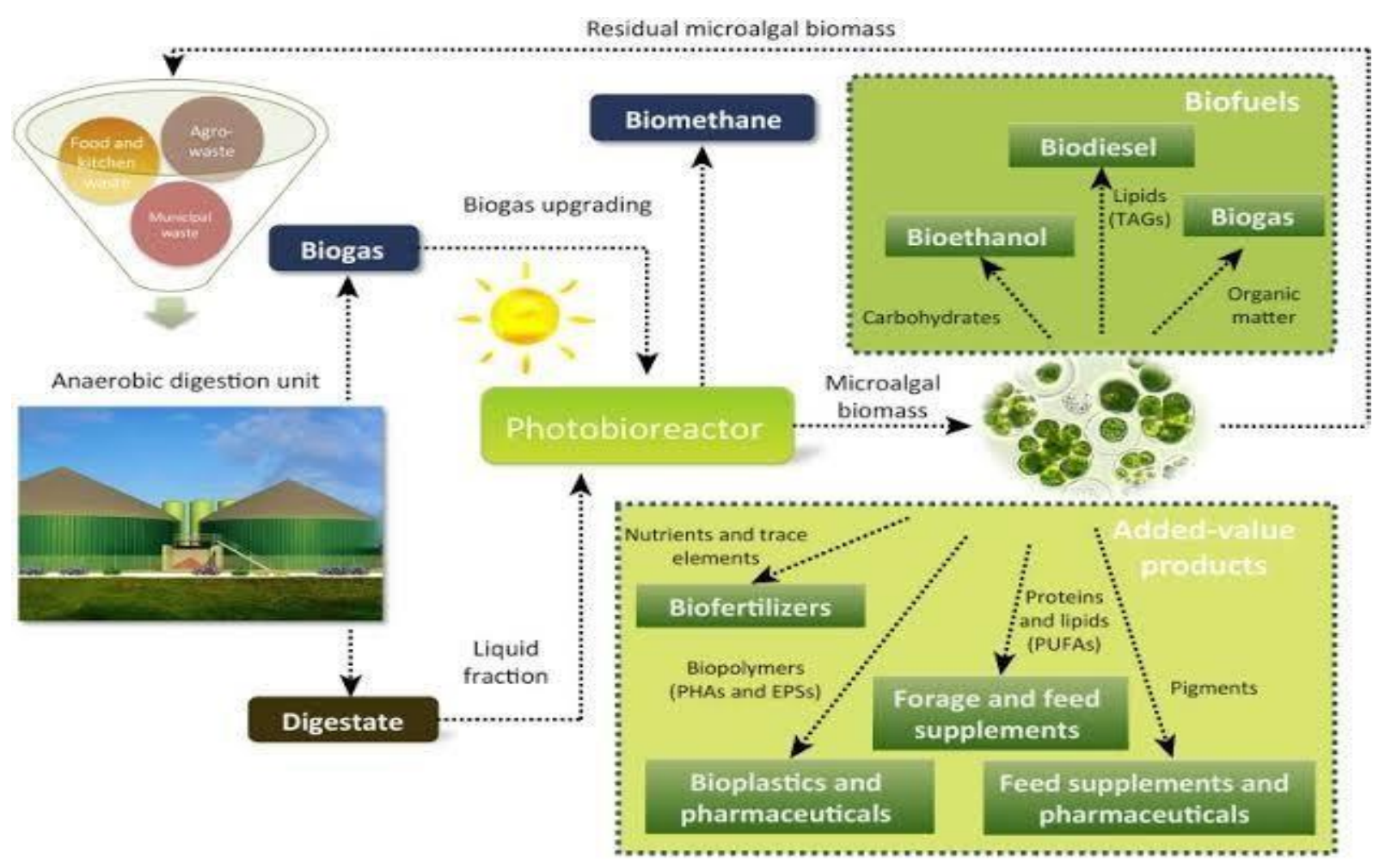

Figure 1 : Application of harvested biomass

\section{FUTURE PROSPECTS}

Sustainable improvisation is required in various areas of algal technologies. Improvements in the cost effective mechanical mixing of avoiding photo inhibition will also improve the economic production of algal biomass in open cultivation systems. The use of various types of waste waters and industrial effluents as culture media will substantially reduce the cost of biomass production, however this needs elaborated research and optimization studies for commercial applications.

\section{CONCLUSIONS}

From the studies it is concluded that bioflocculation of microlgae can be used as a more practical alternative ecofriendly approach for waste water treatment to eliminate eutrophication. High nutrient removal efficiency is obtained. The algal species was able to remove ammonium, nitrate, phosphate, total phosphorous, COD, BOD .Conventional methods need yet to be economically sustainable due to high energy consumption. Use of chemical flocculants is undesirable because it cause some environmental problems. So bioflocculation will be an alternative approach as it is toxic free. Waste water can be used as a cost effective growth medium for algae. Besides waste water treatment the harvested biomass has several secondary applications also. The successful application of 
Sustainability, Agri, Food and Environmental Research, (ISSN: 0719-3726), 10(X), 2022:

http://dx.doi.org/

bioflocculation would develop low energy and chemical free sustainable waste water treatment. The bioflocculant studies are mainly focused at labortary scale. To make this technology practically viable, the potential of bioflocculant need to be evaluated and improved at large scale. However it is not economical as chemical flocculants, so researchers must be focused on reducing cost of production

\section{REFERENCES}

1. Zhiong Chen, Shashan Shao, Mingminzheg. 2020. Nutrient removal from piggery waste water coupled to lipid production by a newly isolated self flocculating microalgae Desmodesmus", Bioresource Technology, 7: 346-356

2. J.F. Freiteg, M. Torres Nazari. 2020. Microalgae harvesting by fungal assiated bioflocculation, Springer Nature, 10: 302-320

3. H Dilliranu Nagarajan, Adi Kusumayadi. 2019. Current advancement in biological swine waste water using microalgae based process", Bioresource technology, 2(6)

4. Jumping LV, Baowen Guo, Jia Fent. 2019. Integration of waste water treatment and flocculation for harvesting biomass for lipid production by a newly isolated self flocculating microalgae", Algal Research, Issue 45

5. Donna L Sutherland, Jason Park, Peter J. 2018. Size matters- Microalgae production and nutrient removal in waste water treatment high rate algal ponds in three different sizes," Bioresource Technology.

6. Than luu pham, maha babui. 2020. Removal of nutrients from fertilizer plant waste water using algae, formation of bioflocculation and enhancement of removal efficiency", Journal of chemistry,8(11), 312-341

7. CN Reddy, HTN Nguyen. 2019. Application of microalgae in waste water treatment", Bioresource Technology.

8. TK Marella, D Sutra. 2017. Biodiesel production through algal cultuvation in urban waste water", Bioresource Technology, 345-378.

9. A L Gonclaves, JCM pires and M Simoes. 2017. A review on the use of microalgal consortia for waste water treatment", Algal Research, 24: 403-415.

10. P. M Glibert, 2017.Eutrophication, harmful algae and biodiversity- challenging paradigms in a world of conplex nutrient changes", Marine pollution Bulletin, 124: 591606.

11. J. M. O'Neil, T. W. Davis, M. A. Burford, and C. J. Gobler. 2016. The rise of harmful cyanobacteria blooms: the potential roles of eutrophication and climate change. Harmful Algae, 14: 313-334.

12. J.Heisler, P.M.Glibert, J.M.Burkholderetal. 2019. Eutrophication and harmful algal blooms: a scientific consensus. Harmful Algae, 8: 3-13. 
Sustainability, Agri, Food and Environmental Research, (ISSN: 0719-3726), 10(X), 2022: http://dx.doi.org/

13. T.-L. Pham and M. Utsumi. 2018. An overview of the accumulation of microcystins inaquaticecosystems," Journal of Environmental Management, 213: 520-529.

14. W. M. Lewis, W. A. Wurtsbaugh, and H. W. Paerl. 2016. Rationale for control of anthropogenic nitrogen and phosphorus to reduce eutrophication of inland waters. Environmental Science \& Technology, 45: 10300-10305

15. N. C. Boelee, H. Temmink, M. Janssen, C. J. N. Buisman, and R. H. Wijffels. 2017. Nitrogen and phosphorus removal from municipal wastewater effluent using microalgal biofilms. Water Research, 45: 5925-5933.

16. Y. Zhao, S. Sun, C. Hu, H. Zhang, J. Xu, and L. Ping. 2017. Performance of three microalgal strains in biogas slurry purification and biogas upgrade in response to various mixed light emitting diode light wavelengths," Bioresource Technology, 187: 338-345

17. L.E. Gonzalez, R.O. Cañizares, and S. Baena. 2018. Efficiency of' ammonia and phosphorus removal from a colombian agroindustrial wastewater by the microalgae Chlorella vulgaris and Scenedesmus dimorphus. Bioresource Technology, 60: 259-262.

18. Muhammad S, Kumar A., Gosh U. 2017. Advanced wastewater treatment using microalgae: Effect of temperature on removal of nutrients and organic carbon", In conference series: Science and environment. 67.

19. Wollmann F, Walther T. 2017. Microalgae wastewater treatment: Biological and technical approaches", Eng life sci, 860-871.

20. Sutherland D.L, Dalph D.J., 2017. Microalgal bioremediation of emerging contaminants opportunities and challenges, Water resources technology, 164.

Received: $15^{\text {th }}$ February 2021; Accepted: $21^{\text {th }}$ April 2021; First distributed: $21^{\text {th }}$ March 2021 